\title{
The Role of Arbuscular Mycorrhizal Fungus (Gigaspora margarita) on Mercury and Nutrients Accumulation by Enterolobium cyclocarpum Seedlings
}

\author{
HANNA ARTUTI EKAMAWANTI ${ }^{1,2}$, YADI SETIADI $^{3 *}$, DIDY SOPANDIE $^{4}$, \\ AND DWI ANDREAS SANTOSA ${ }^{5}$
}

\author{
${ }^{\prime}$ Tropical Silviculture Major, Post-graduate School, Institut Pertanian Bogor, \\ Jalan Lingkar Akademik Kampus IPB Darmaga, Bogor 16680, Indonesia; \\ ${ }^{2}$ Faculty of Forestry, Universitas Tanjungpura, Jalan Imam Bonjol, Pontianak, Indonesia; \\ ${ }^{3}$ Laboratory of Forest Biotechnology, Research Center for Biological Resources and Biotechnology, \\ Institut Pertanian Bogor, Jalan Lingkar Akademik Kampus IPB Darmaga, Bogor 16880, Indonesia; \\ ${ }^{4}$ Department of Agronomy and Horticulture, Institut Pertanian Bogor, Jalan Meranti, \\ Kampus IPB Darmaga, Bogor 16680, Indonesia; \\ ${ }^{5}$ Laboratory of Biotechnology Soil and Environment, Department of Soil and Land Resources, Institut Pertanian Bogor, \\ Jalan Meranti, Kampus IPB Darmaga, Bogor 16680, Indonesia
}

\begin{abstract}
A river-sand culture experiment was conducted to investigate whether arbuscular mycorrhizal (AM) colonization influenced mercury (Hg) and nutrients accumulation, and whether AM fungus (AMF) Gigaspora margarita enhance host plant sengon buto (Enterolobium cyclocarpum) tolerance to $\mathrm{Hg}$. $\mathrm{Hg}$ was applied as $\mathrm{HgCl}_{2}$ at different levels ( 375 and $750 \mu \mathrm{M}$ ) and added to the full strength of Hoagland's solution, then applied to seedlings in river-sands as growth media according to treatments. The non-mycorrhizal and mycorhizal $E$. cyclocarpum roots took up $\mathrm{Hg}$, but its translocation to the leaves was inhibited. AM inoculation decreased significantly $\mathrm{Hg}$ content of roots seedlings by $70.5 \%$ from non-AM inoculation seedlings. Mycorrhizae enhanced significantly $\mathrm{Ca}$ and $\mathrm{Mg}$ uptake in shoot by 1.29- and 1.27-fold higher than non-mycorrhizal seedlings, but not enhanced significantly P uptake. Based on the roots dry weight, the tolerance index of non-mycorrhizal or mycorrhizal seedlings treated with $750 \mu \mathrm{M} \mathrm{Hg}$ supply was $>50 \%$. It indicated that the seedlings can tolerate up to $750 \mu \mathrm{M} \mathrm{Hg}$ added. Considering the possible differences in AMF response to $\mathrm{Hg}$ in polluted soil from the field, it is not yet clear if Gi. margarita could be applied for phytoremediation of $\mathrm{Hg}$ in contaminated sites. Therefore, more work needs to be done using AMF isolates to reveal the possible application in the management of $\mathrm{Hg}$ contaminated soils.
\end{abstract}

Key words: arbuscular mycorrhizal fungus, Enterolobium cyclocarpum, Gigaspora margarita, mercury

Percobaan untuk meneliti apakah kolonisasi mikoriza arbuskula (MA) mempengaruhi akumulasi merkuri $(\mathrm{Hg})$ dan unsur hara, dan apakah fungi MA (FMA) Gigaspora margarita meningkatkan toleransi tanaman inang Sengon Buto (Enterolobium cyclocarpum) terhadap Hg telah dilakukan. Perlakuan Hg diberikan dengan konsentrasi berbeda ( 375 dan $750 \mu \mathrm{M} \mathrm{HgCl}_{2}$ ) yang ditambahkan ke dalam larutan hara Hoagland full strength, kemudian diberikan pada semai di media tumbuh pasir sungai sesuai perlakuan. Akar E. cyclocarpum tidak bermikoriza dan bermikoriza menyerap $\mathrm{Hg}$, tetapi translokasinya ke daun dihambat. Inokulasi MA nyata menurunkan kadar Hg akar semai 75\% dari semai yang tidak diinokulasi MA. Mikoriza nyata meningkatkan serapana $\mathrm{Ca}$ dan $\mathrm{Mg}$ di tajuk 1.29 dan 1.27 kali lebih tinggi dari semai tidak bermikoriza, tetapi tidak nyata meningkatkan serapan P. Berdasarkan bobot kering akar, indeks toleransi semai tidak bermikoriza dan bermikoriza yang diberi perlakuan $\mathrm{Hg} 750 \mu \mathrm{M}$ lebih dari 50\%. Hal ini mengindikasikan bahwa semai dapat toleran Hg hingga $750 \mu \mathrm{M}$. Pertimbangan pada kemungkinan perbedaan respons FMA terhadap Hg di tanah tercemari dari lapangan, masih belum jelas apakah Gi. margarita dapat diaplikasikan untuk fitoremediasi lahan terkontaminasi Hg. Oleh karena itu, penelitian lebih lanjut dengan memanfaatkan isolat-isolat FMA diperlukan untuk mengembangkan kemungkinan aplikasinya dalam pengelolaan tanah-tanah terkontaminasi Hg.

Kata kunci: Enterolobium cyclocarpum, fungi mikoriza arbuskula, Gigaspora margarita, merkuri

Numerous soils have been polluted by mercury $(\mathrm{Hg})$ as a result of anthropogenic activities, such as amalgamation of gold in gold-mining and the agricultural soils. $\mathrm{Hg}$ is a toxic chemical which is not degraded because it is an element (US EPA 2009). Management of

*Corresponding author; Phone/Fax: +62-251-8626178, Email:hanna.artuti@gmail.com the areas, which have been exposed to either intense or diffuse $\mathrm{Hg}$ pollution, has therefore become a major environmental concern. Strategies oriented toward the use of plants and microbes, or both in combinations within the plant rhizosphere, have been proposed in the recent years as an effective cleanup technology in removing or stabilizing heavy metals in polluted soils.

Among these microbes, arbuscular mycorrhizal 
fungi (AMF) are particular interest due to their unique position at the soil/root interface and their recognized role in element transport and immobilization (Smith and Read 2008). AMF can tolerate a wide range of metal concentrations in soils (González-Guerrero et al. 2008), affect the accumulation of metals such as $\mathrm{Cu}$, $\mathrm{Cd}, \mathrm{Zn}$, and As by plants and enhance the tolerance of host plants to these metals exposure in soil (GonzálezChávez et al. 2004; Janoušková et al. 2006; Marques et al. 2006). However, few studies have addressed the interaction between AMF and $\mathrm{Hg}$ in growth mediumor soil-plant system. Therefore, the potential of AMF has not yet been fully explored with respect to its $\mathrm{Hg}$ phytoremediation. The first report about the effects of $\mathrm{AM}$ inoculation on $\mathrm{Hg}$ behavior in soil-plant system is done by Yu et al. (2010) and it has been shown that $\mathrm{Hg}$ uptake was lower by mycorrhizal roots of maize than by non-mycorrhizal roots. $\mathrm{Hg}$ accumulation in several plants has been studied, such as white clover (Greger et al. 2005), alfalfa (Ortega-Villasante et al. 2005), lentil, chickpea (Rodríguez et al. 2007) and common vetch (Sierra et al. 2008). Nevertheless, very few studies have been conducted on the $\mathrm{Hg}$ tolerance in tropical trees, such as Sengon Buto (Enterolobium cyclocarpum). This species is one of the largest trees in the dry forest formation and a nitrogen-fixing species (World Agroforestry Centre 2013), therefore it could be a soil improver. If this tree species is proposed for phytoremediation on Hg-polluted soil, plant Hg uptake and resistance response should be evaluated under controlled conditions, prior to field establishment a screen to identify suitable candidate species.

The interaction between AMF, tree species (such as E. cyclocarpum) and $\mathrm{Hg}$ was the subject of this study because of the possibility of the beneficial effect of mycorrhizae in improving the resistance of plants against $\mathrm{Hg}$ toxicity. The study was carried out to determine the $\mathrm{Hg}$ and nutrient accumulation in $E$. cyclocarpum seedlings inoculated with AMF Gigaspora margarita (collection of Laboratory of Forest Biotechnology, Research Center for Biological Resources and Biotechnology, Bogor Agricultural University) grown in artificial Hg-polluted river sands media in pot experiment. Such knowledge would help clarify the potential of tree species E. cyclocarpum and $\mathrm{AMF}$ as phytoremediation agents of $\mathrm{Hg}$-polluted soils.

\section{MATERIALS AND METHODS}

Plant Culture in River Sands at Different Rates of Hg. E. cyclocarpum seeds were surface-sterilized by immersing the seeds in $0.05 \% \mathrm{NaOCl}$ for $60 \mathrm{sec}$ and then rinsing them three times with distilled water $\left(\mathrm{dH}_{2} \mathrm{O}\right)$. To break dormancy, the seeds were soaked in boiling water for $5 \mathrm{~min}$ and then in $\mathrm{dH}_{2} \mathrm{O}$ overnight. The seeds were germinated on zeolite media. After formation of completed leaves, a seedling was transplanted on to zeolite media in polybag $(15 \mathrm{~cm}$ x 25 $\mathrm{cm})$. Mycorrhizal seedlings were obtained by inoculating the seedlings with Gi. margarita inoculums (Laboratory of Forest Biotechnology, Research Center for Biological Resources and Biotechnology, Bogor Agricultural University collection) as first inoculation First inoculation of AMF inoculum when they were germinated and transplanted on zeolite. Each nine-months old seedlings of non-mycorrhizal and mycorrhizal was grown in a PVC pot $(10 \mathrm{~cm}$ in diameter and $30 \mathrm{~cm}$ in height), containing $5 \mathrm{~kg}$ coarse river sands $(1-2 \mathrm{~mm}$ ) as substrate and maintained in screen house. Gi. margarita inoculum $(25 \mathrm{~g})$ was inoculated to mycorhizal seedlings for second inoculation and sterilized mycorrhizal inoculum ( $25 \mathrm{~g})$ and its filtrate (10 mL each pot) was applied to non-mycorrhizal seedlings. All seedlings were maintained by adding the nutrient solution for 8 weeks. The composition of the nutrient solution was as follows $\left(\mathrm{mmol} \mathrm{L}^{-1}\right)$ (Zornoza et al. 2010): $\mathrm{Ca}\left(\mathrm{NO}_{3}\right)_{2} 1.5 ; \mathrm{KNO}_{3} 4.0 ; \mathrm{KH}_{2} \mathrm{PO}_{4} 1.5$ and $\mathrm{MgSO}_{4}$ 1.0. Micronutrients were supplied $\left(\mu \mathrm{mol} \mathrm{L}^{-1}\right)$ : Fe-EDDHA 36; $\mathrm{MnSO}_{4} \cdot \mathrm{H}_{2} \mathrm{O}$ 33; $\mathrm{ZnSO}_{4} \cdot 7 \mathrm{H}_{2} \mathrm{O}$ 1.6; $\mathrm{CuSO}_{4} .5 \mathrm{H}_{2} \mathrm{O} 1.6 ; \mathrm{H}_{3} \mathrm{BO}_{3} 46$, and $\left(\mathrm{NH}_{4}\right)_{6} \mathrm{Mo}_{7} \mathrm{O}_{24} \cdot 4 \mathrm{H}_{2} \mathrm{O}$ 0.1 . The $\mathrm{pH}$ of nutrient solution ranged for 5.5 to 6.0 . A factorial experiment with completely randomized design with three replicates for each treatment was used. $\mathrm{Hg}$ treatments were 0,375 and $750 \mu \mathrm{M}$, supplied as $\mathrm{HgCl}_{2}$ salt and applied to E. cyclocarpum seedlings, either with or without AM inoculation treatments. These concentration of $\mathrm{Hg}$ treatments were threshold concentration of $\mathrm{Hg}$ toxicity for E. cyclocarpum seedlings based on the result of previous research. The experiment was carried out in screen house of Forest Microbiology Laboratory, Agency for the Research of Forest Rehabilitation and Conservation, Bogor, under the following conditions: $28^{\circ} \mathrm{C}-33^{\circ} \mathrm{C}$ temperature and $80 \%-95 \%$ humidity.

Harvesting. Plants were harvested after $30 \mathrm{~d}$ to $\mathrm{Hg}$ exposure and divided into roots, stems and leaves. All plant material was thoroughly washed with tap water followed by a subsequent rinse in $20 \mathrm{mM}$ EDTA solution for $1 \mathrm{~min}$ and then in deionized water for 2 min. Total fresh weight of each tissue was determined, then a representative plants were oven-dried to 
constant weight at $70{ }^{\circ} \mathrm{C}$ for $3 \mathrm{~d}$ prior to preparation for measuring dry weights and nutrients analysis, and at 50 ${ }^{\circ} \mathrm{C}$ prior to preparation for $\mathrm{Hg}$ analysis. Water content was determined based on the difference of fresh weight and dry weight. The rest of the material plants was frozen in liquid $\mathrm{N}_{2}$ and stored at $-20{ }^{\circ} \mathrm{C}$ before malondialdehyde (MDA) concentration analyzing.

Analytical determination. Dried plant sample was acid digested using $25 \mathrm{~mL}$ of deionized water, 3.5 $\mathrm{mL}$ of concentrated $\mathrm{HNO}_{3}$ and $0.5 \mathrm{~mL}$ of $\mathrm{HClO}_{4}$, added to $0.5 \mathrm{~g}$ dry weight (DW) in a test tube. The digested solution was analyzed for $\mathrm{Hg}$ concentration using inductively coupled plasma-optical emission spectrometry (ICP-OES, Spectro Genesis) excitation, and calibration was performed by using standard $\mathrm{Hg}$ solution (Han et al. 2006). Total Hg and nutrient (P, Ca, and $\mathrm{Mg}$ ) concentration were determined by ICP-OES. Lipid peroxidation in plant tissues was based on an estimate of malondialdehyde (MDA) concentration, as described by Heath and Packer (Ortega-Villasante et al. 2005). AM colonization was determined following Brundrett et al.(1996).

Calculation. Some variables were calculated to study the resistance to mercury stress of $E$. cyclocarpum seedlings (Moreno-Jiménez et al. 2007): $\mathrm{Hg}$ content in roots $\left(\mathrm{ng}\right.$ roots $\left.^{-1}\right)$
and leaves $(\mathrm{ng}$ leaves

where $[\mathrm{Hg}]$ was $\mathrm{Hg}$ concentration, and DW was the roots or leaves dry weight.

Nutrient uptake $\left(\mathrm{nmol} \mathrm{g}^{-1} \mathrm{DW}\right)=\frac{\mathrm{nmol} \mathrm{plant}^{-1}}{\mathrm{~g} \mathrm{DW}}$

Nutrients $(\mathrm{P}, \mathrm{Ca}$ and $\mathrm{Mg}$ ) uptake and translocation were calculated as (Wang and Greger 2004):

Nutrient translocation $\left(\mathrm{nmol} \mathrm{Hg} \mathrm{g}^{-1} \mathrm{DW}\right)=\frac{\text { nmol leaves }^{-1}}{\mathrm{~g} \mathrm{DW}}$ where DW was the entire-plant dry weight.

Tolerance index (TI) of mycorrhizal and nonmycorrhizal seedlings to $\mathrm{Hg}$ treatments was determined based on roots dry weight, as (Rabie 2005):

$$
\mathrm{TI}(\%)=\frac{\begin{array}{c}
\text { DW of roots } \\
\text { at } \mathrm{Hg} \text { treated }
\end{array}}{\begin{array}{c}
\text { DW roots at non } \mathrm{Hg} \text { treated } \\
\text { of the same treatments }
\end{array}} \times 100
$$

Water content (WC) of leaves, stems or roots was calculated as:

$$
\mathrm{WC}(\%)=\frac{(\mathrm{FW}-\mathrm{DW}) \text { of leaves, stems, or roots }}{\text { FW of leaves, stems, or roots }} \times 100
$$

where FW was fresh weight.

Statistical analyzes. A statistical analyzes for means comparison was carried out using ANOVA and least significant difference (LSD) test using statistical software CoStat 6.400.

\section{RESULTS}

Mercury Accumulation. $\mathrm{Hg}$ accumulation in $E$. cyclocarpum seedlings was affected significantly by $\mathrm{Hg}$ treatment. $\mathrm{Hg}$ concentration in roots of $E$. cyclocarpum seedlings was 8- to 16-fold and $\mathrm{Hg}$ content in roots was 3- to 6-fold higher than the control (without $\mathrm{Hg}$ ) (Table 1). However, at the $750 \mu \mathrm{M}$ of Hg, $\mathrm{Hg}$ accumulation in roots was decreased significantly by $49.6 \%$ of $\mathrm{Hg}$ concentration and $57.2 \%$ of $\mathrm{Hg}$ content when compared to $\mathrm{Hg}$ accumulation in roots of seedlings treated with $375 \mu \mathrm{M}$ of $\mathrm{Hg}$. $\mathrm{Hg}$ accumulation in roots without $\mathrm{Hg}$ treatment shows that there was $\mathrm{Hg}$ cross contamination in the air. Table 1 shows that almost there are not $\mathrm{Hg}$ accumulation in leaves of $E$. cyclocarpum. On the other hand, AM inoculation decreased $\mathrm{Hg}$ content of roots seedlings by $70.5 \%$ from non-AM inoculation seedlings (data not shown).

Nutrients Accumulation and Distribution. The highest $\mathrm{Hg}$ concentration had stronger effects regarding nutrients translocation than regarding nutrients uptake, especially in mycorrhizal seedlings (Table 2). The supply of $750 \mu \mathrm{M} \mathrm{Hg}$ caused reducing in $\mathrm{P}$ and $\mathrm{Mg}$ translocation by $53 \%$ and $47 \%$, respectively, lower than the control (without $\mathrm{Hg}$ supply) in mycorrhizal seedlings. P uptake also followed a similar response to highest $\mathrm{Hg}$ rate by $29 \%$ lower than the control in seedlings inoculated with AMF. In contrast, nutrients $(\mathrm{P}, \mathrm{Ca}$, and $\mathrm{Mg})$ uptake and translocation were not difference in non-mycorrhizal seedlings treated with the Hg supply. Moreover, nutrients uptake and translocation did not suffer decreases in seedlings at the lower $\mathrm{Hg}$ supply $(375 \mu \mathrm{M})$, either in non-mycorrhizal or mycorrhizal seedlings.

Table 2 also showed that AM inoculation had negative effects regarding nutrients translocation, but not regarding nutrients uptake in seedlings treated with the $\mathrm{Hg}$ supply. The AM inoculation caused decreases significantly in $\mathrm{P}$ and $\mathrm{Mg}$ translocation to leaves by $56 \%$ and $44 \%$, respectively, lower than in nonmycorrhizal seedlings treated with $750 \mu \mathrm{M} \mathrm{Hg}$ apply. In contrast, $\mathrm{P}$ and $\mathrm{Mg}$ uptake showed no difference effects of between control (no AM inoculation) and AM inoculation in seedlings at $375 \mu \mathrm{M} \mathrm{Hg}$ supply. This 
Table $1 \mathrm{Hg}$ concentration and $\mathrm{Hg}$ content in roots and leaves of E. cyclocarpum seedlings grown for $30 \mathrm{~d}$ in river sands with treatment of different $\mathrm{Hg}$ concentration

\begin{tabular}{ccccl}
\hline Hg $(\mu \mathrm{M})$ & \multicolumn{2}{c}{ Hg concentration $\left(\mathrm{ng} \mathrm{g}^{-1} \mathrm{DW}\right)$} & \multicolumn{2}{c}{ Hg content $(\mathrm{ng})$} \\
\cline { 2 - 5 } & Roots & Leaves & Roots & Leaves \\
\hline 0 & $38.2 \pm 26.2 \mathrm{a}$ & $1.8 \pm 3.0$ & $363.5 \pm 467.4 \mathrm{a}$ & $9.6 \pm 14.7$ \\
375 & $611.0 \pm 124.3 \mathrm{c}$ & n.d & $2,066.5 \pm 1,759.0 \mathrm{c}$ & n.d \\
750 & $302.8 \pm 154.8 \mathrm{~b}$ & n.d & $1,183.0 \pm 991.1 \mathrm{~b}$ & n.d
\end{tabular}

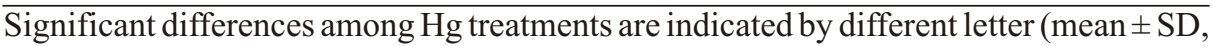
$\mathrm{n}=6$; LSD's test, $\mathrm{p}<0.05)$. DW: dry weight.

Table 2 Nutrients uptake and translocation in E. cyclocarpum seedlings grown for $30 \mathrm{~d}$ in river sands with treatments of different $\mathrm{Hg}$ concentrations and AM inoculation

\begin{tabular}{|c|c|c|c|c|}
\hline \multirow{2}{*}{$\operatorname{Hg}(\mu \mathrm{M})$} & \multicolumn{4}{|c|}{$\mathrm{AM}$ inoculation } \\
\hline & Without & With & With out & With \\
\hline & \multicolumn{2}{|c|}{----- P uptake $\left(\mu \mathrm{mol} \mathrm{g}{ }^{-1} \mathrm{DW}\right)$------ } & \multicolumn{2}{|c|}{------ P translocation $(\mu \mathrm{mol}$ g-1 DW) ------ } \\
\hline 0 & $109.8 \pm 23.3 \mathrm{a}(\mathrm{B})$ & $164.7 \pm 14.8 \mathrm{a}(\mathrm{A})$ & $19.3 \pm 7.3 \mathrm{a}(\mathrm{A})$ & $29.2 \pm 8.3 \mathrm{a}(\mathrm{A})$ \\
\hline 375 & $127.0 \pm 8.1 \mathrm{a}(\mathrm{A})$ & $162.5 \pm 21.5 \mathrm{a}(\mathrm{A})$ & $23.4 \pm 6.0 \mathrm{a}(\mathrm{A})$ & $28.5 \pm 16.1 \mathrm{a}(\mathrm{A})$ \\
\hline \multirow[t]{2}{*}{750} & $142.1 \pm 36.7 \mathrm{a}(\mathrm{A})$ & $116.2 \pm 21.2 \mathrm{~b}(\mathrm{~A})$ & $30.2 \pm 0.7 \mathrm{a}(\mathrm{A})$ & $13.3 \pm 2.5 \mathrm{~b}(\mathrm{~B})$ \\
\hline & \multicolumn{2}{|c|}{----- Ca uptake ( $\left.\mu \mathrm{mol} \mathrm{g}^{-1} \mathrm{DW}\right)$------ } & \multicolumn{2}{|c|}{------ Ca translocation $\left(\mu \mathrm{mol} \mathrm{g}{ }^{-1} \mathrm{DW}\right)$------ } \\
\hline 0 & $60.0 \pm 3.3 \mathrm{a}(\mathrm{A})$ & $84.3 \pm 14.3 \mathrm{a}(\mathrm{A})$ & $65.1 \pm 21.8 \mathrm{a}(\mathrm{A})$ & $93.4 \pm 30.5 \mathrm{a}(\mathrm{A})$ \\
\hline 375 & $47.7 \pm 2.6 \mathrm{a}(\mathrm{A})$ & $60.9 \pm 12.2 \mathrm{a}(\mathrm{A})$ & $54.1 \pm 10.3 \mathrm{a}(\mathrm{A})$ & $61.7 \pm 18.9 \mathrm{a}(\mathrm{A})$ \\
\hline \multirow[t]{2}{*}{750} & $50.0 \pm 3.2 \mathrm{a}(\mathrm{A})$ & $58.7 \pm 3.6 \mathrm{a}(\mathrm{A})$ & $68.6 \pm 15.0 \mathrm{a}(\mathrm{A})$ & $42.6 \pm 11.6 \mathrm{a}(\mathrm{A})$ \\
\hline & \multicolumn{2}{|c|}{------ Mg uptake $\left(\mu \mathrm{mol} \mathrm{g}{ }^{-1} \mathrm{DW}\right)$------ } & \multicolumn{2}{|c|}{------ Mg translocation $\left(\mu \mathrm{mol} \mathrm{g}{ }^{-1} \mathrm{DW}\right)$----- } \\
\hline 0 & $23.3 \pm 2.3 \mathrm{a}(\mathrm{A})$ & $34.5 \pm 8.6 \mathrm{a}(\mathrm{A})$ & $67.9 \pm 19.7 \mathrm{a}(\mathrm{A})$ & $102.4 \pm 32.1 \mathrm{a}(\mathrm{A})$ \\
\hline 375 & $24.4 \pm 1.3 \mathrm{a}(\mathrm{A})$ & $31.5 \pm 2.2 \mathrm{a}(\mathrm{A})$ & $75.5 \pm 15.5 \mathrm{a}(\mathrm{A})$ & $88.6 \pm 31.1 \mathrm{a}(\mathrm{A})$ \\
\hline 750 & $23.3 \pm 6.4 \mathrm{a}(\mathrm{A})$ & $24.6 \pm 7.3 \mathrm{a}(\mathrm{A})$ & $83.6 \pm 3.8 \mathrm{a}(\mathrm{A})$ & $46.9 \pm 8.3 \mathrm{~b}(\mathrm{~B})$ \\
\hline
\end{tabular}

Significant differences among Hg treatments are indicated by small different letter and among AM inoculation treatments with different capital letters (mean $\pm \mathrm{SD}, \mathrm{n}=3$; LSD's test, $\mathrm{p}<0.05$ ). DW: dry weight.

tendency was also found regarding $\mathrm{Ca}$ uptake and translocation. On the other hand, AM inoculation increased $\mathrm{P}$ uptake, significantly, and tended to increase $\mathrm{Ca}$ and $\mathrm{Mg}$ uptake and also nutrients translocation in seedlings treated without $\mathrm{Hg}$ supply. In addition, AM inoculation as a single factor treatment also enhanced $\mathrm{Ca}$ and $\mathrm{Mg}$ uptake in seedlings, significantly, by 1.29- and 1.27-fold higher than nonmycorrhizal seedlings, respectively (Table 3 ).

E. cyclocarpum Seedlings Biomass and MDA Concentration. The negative effect of $\mathrm{Hg}$ in plants was reflected in biomass (dry weight), being significantly $(p<0.05)$ reduced in non-mycorrhizal and mycorrhizal seedlings, when cultivated with $\mathrm{Hg}$ supply (Table 4). Dry weight of leaves, stems and roots decreased in the range $38-54 \%, 54-67 \%$, and $43-54 \%$, respectively. It indicated that there was reduction of plant growth caused by $\mathrm{Hg}$ supply up to $750 \mu \mathrm{M}$ during $30 \mathrm{~d}$ of $\mathrm{Hg}$ exposure.

On the other hand, biomass of seedling treated with AM inoculation was decreased significantly (Table 5). In stems and roots, E. cyclocarpum seedlings treated with AM inoculation showed $63 \%$ and $68 \%$ decrease in the biomass respectively, but a sharp decrease (72\%) was occurred in leaves.

Regarding water content (Table 6), the effect of AM inoculation depended on $\mathrm{Hg}$ treatment. At control (without $\mathrm{Hg}$ supply), leaves and stems water content in 
Table 3 Nutrients uptake in E. cyclocarpum seedlings grown for $30 \mathrm{~d}$ in river sands with treatment of mycorrhizal

\begin{tabular}{lccc}
\hline AM inoculation & $\begin{array}{c}\text { P uptake } \\
\left(\mu \mathrm{mol} \mathrm{g}^{-1} \mathrm{DW}\right)\end{array}$ & $\begin{array}{c}\text { Ca uptake } \\
\left(\mu \mathrm{mol} \mathrm{g}^{-1} \mathrm{DW}\right)\end{array}$ & $\begin{array}{c}\text { Mg uptake } \\
\left(\mu \mathrm{mol} \mathrm{g}{ }^{-1} \mathrm{DW}\right)\end{array}$ \\
\hline Without & $126.3 \pm 26.2 \mathrm{a}$ & $52.6 \pm 6.3 \mathrm{~b}$ & $23.7 \pm 3.5 \mathrm{~b}$ \\
With & $147.8 \pm 29.1 \mathrm{a}$ & $68.0 \pm 15.6 \mathrm{a}$ & $30.2 \pm 7.2 \mathrm{a}$
\end{tabular}

$\overline{\text { Significant differences among } \mathrm{Hg} \text { treatments are indicated by different letter (mean } \pm \mathrm{SD}, \mathrm{n}}$ $=9$; LSD's test, $\mathrm{p}<0.05)$. DW: dry weight.

Table 4 Leaves, stems and roots dry weight of E. cyclocarpum seedlings grown for $30 \mathrm{~d}$ in river sands with treatments of different $\mathrm{Hg}$ concentrations

\begin{tabular}{llrc}
\hline \multirow{2}{*}{$\mathrm{Hg}(\mu \mathrm{M})$} & \multicolumn{3}{c}{ Dry weight $(\mathrm{g})$} \\
\cline { 2 - 4 } & Roots & \multicolumn{1}{c}{ Stems } & Leaves \\
\hline 0 & $7.0 \pm 4.8 \mathrm{a}$ & $11.1 \pm 5.6 \mathrm{a}$ & $3.7 \pm 2.2 \mathrm{a}$ \\
375 & $3.2 \pm 2.5 \mathrm{~b}$ & $3.7 \pm 2.7 \mathrm{~b}$ & $1.7 \pm 1.6 \mathrm{~b}$ \\
750 & $4.0 \pm 2.9 \mathrm{~b}$ & $5.1 \pm 4.4 \mathrm{~b}$ & $2.3 \pm 2.1 \mathrm{~b}$ \\
\hline
\end{tabular}

Significant differences among $\mathrm{Hg}$ treatments are indicated by different letter (mean \pm SD, $\mathrm{n}=6$; LSD's test, $\mathrm{p}<0.05$ ). DW: dry weight.

mycorrhizal seedlings were increased by $11 \%$ each. Even though AM inoculation did enhance leaves water content, it increased stems water content significantly by $27 \%$ when the seedlings were exposed to $750 \mu \mathrm{M}$ Hg. Moreover, mycorrhizal inoculation enhanced roots water content, $17 \%$ higher than non-mycorrhizal, in seedlings treated with or without $\mathrm{Hg}$ treatments (data not shown).

$\mathrm{Hg}$ exposure for $30 \mathrm{~d}$ increased MDA concentration in roots of E. cyclocarpum seedlings, significantly (Fig 1). MDA concentration of roots increased when the seedlings were grown in $\mathrm{Hg}$-treated river-sand media, either with or without AM inoculation. AM inoculation caused the highest increase in MDA concentration by $485 \%$ in the roots of seedlings treated with $750 \mu \mathrm{M} \mathrm{Hg}$, when compared to the control (without AM inoculation). On the other hand, $375 \mu \mathrm{M}$ and $750 \mu \mathrm{M}$ $\mathrm{Hg}$ supply resulted in the increased MDA concentration in leaves by $14 \%$ and $97 \%$, respectively (data not shown).

Tolerance index of E. cyclocarpum seedlings grown for $30 \mathrm{~d}$ in river sands treated with $375 \mu \mathrm{M} \mathrm{Hg}$ was $<50 \%$ but the tolerance index was $>54 \%$ when the seedlings were treated with $750 \mu \mathrm{M}$ (Table 7). Roots of non-inoculated seedlings remained nonmycorrhizal while roots of inoculated ones were colonized by AMF (Table 7). The low AMF colonization in seedlings treated with $\mathrm{Hg}$ indicated that Gi. margarita colonization was reduced in the presence of Hg in substrate.

\section{DISCUSSION}

The results obtained during this research have shown that AMF Gi. margarita decreased $\mathrm{Hg}$ content in root seedlings. We predicted that decreasing $\mathrm{Hg}$ content in roots is one of $\mathrm{Hg}$ tolerance mechanisms in mycorrhizal symbiosis. This result was in line with $\mathrm{Yu}$ et al. (2010), AMF Glomus mosseae decreased significantly $\mathrm{Hg}$ concentration in maize roots when $\mathrm{Hg}$ was applied at the rates of 2.0 dan $4.0 \mathrm{mg} \mathrm{kg}^{-1}$. All interactions of $\mathrm{Hg}$ with soil/growth media, roots, and AMF influence its uptake by plants, but this presume need to be investigated in further research. On the other hand, $\mathrm{Hg}$ accumulation in roots treated with $750 \mu \mathrm{M}$ of $\mathrm{Hg}$ supply decreased significantly by $49.6 \%$ of $\mathrm{Hg}$ concentration and $57.2 \%$ of $\mathrm{Hg}$ content when compared to $\mathrm{Hg}$ accumulation in roots of seedlings treated with $375 \mu \mathrm{M}$ of $\mathrm{Hg}$. It shows that at the highest $\mathrm{Hg}$ treatment, $\mathrm{Hg}$ accumulation in root seedlings was limited. This result was in contrast with Esteban et al. (2008) result, which found the pattern of long-term (over 28 d) $\mathrm{Hg}$ accumulation in shoots and roots white lupin (Lupinus albus L.) can be dissected into linear and hyperbolic (saturable) components, when they were grown in 5 and $10 \mu \mathrm{M} \mathrm{Hg}$ supply in hydrophonics. The result of experiment also showed that a main part of $\mathrm{Hg}$ accumulated by E. cyclocarpum 
Table 5 Leaves, stems and roots dry weight of E. cyclocarpum seedlings grown for $30 \mathrm{~d}$ in river sands with treatments of AM inoculation

\begin{tabular}{lccr}
\hline \multirow{2}{*}{ AM inoculation } & \multicolumn{3}{c}{ Dry weight $(\mathrm{g})$} \\
\cline { 2 - 4 } & Roots & Stems & Leaves \\
\hline Without & $7.2 \pm 3.7 \mathrm{a}$ & $9.6 \pm 5.1 \mathrm{a}$ & $3.9 \pm 1.9 \mathrm{a}$ \\
With & $2.3 \pm 1.4 \mathrm{~b}$ & $3.6 \pm 3.6 \mathrm{~b}$ & $1.1 \pm 0.9 \mathrm{~b}$ \\
\hline
\end{tabular}

Significant differences among $\mathrm{Hg}$ treatments are indicated by different letter (mean $\pm \mathrm{SD}, \mathrm{n}$ $=9$; LSD's test, $\mathrm{p}<0.05$ )

Table 6 Roots, stems, and leaves water content of E. cyclocarpum seedlings grown for $30 \mathrm{~d}$ in river sands with treatments of different $\mathrm{Hg}$ concentrations and $\mathrm{AM}$ inoculation

\begin{tabular}{|c|c|c|c|c|c|c|}
\hline \multirow{2}{*}{$\mathrm{Hg}(\mu \mathrm{M})$} & \multicolumn{6}{|c|}{ AM inoculation } \\
\hline & Without & With & Without & With & Without & With \\
\hline & \multicolumn{6}{|c|}{ Water content (\%) } \\
\hline & \multicolumn{2}{|c|}{--------------Roots -------------- } & \multicolumn{2}{|c|}{-------------- Stems --------------- } & \multicolumn{2}{|c|}{ 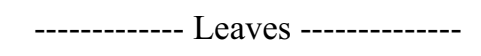 } \\
\hline 0 & $56.1 \pm 9.3 \mathrm{a}(\mathrm{A})$ & $73.3 \pm 3.3 \mathrm{a}(\mathrm{A})$ & $61.3 \pm 2.8 \mathrm{~b}(\mathrm{~B})$ & $68.0 \mathrm{a} \pm 2.1 \mathrm{a}(\mathrm{A})$ & $68.3 \pm 2.9 \mathrm{~b}(\mathrm{~B})$ & $75.8 \pm 0.3 \mathrm{a}(\mathrm{A})$ \\
\hline 375 & $66.3 \pm 4.0 \mathrm{a}(\mathrm{A})$ & $74.9 \pm 7.2 \mathrm{a}(\mathrm{A})$ & $67.1 \pm 2.8 \mathrm{a}(\mathrm{A})$ & $66.7 \mathrm{a} \pm 2.6 \mathrm{a}(\mathrm{A})$ & $73.3 \pm 1.2 \mathrm{a}(\mathrm{A})$ & $72.3 \pm 4.0 \mathrm{a}(\mathrm{A})$ \\
\hline 750 & $69.2 \pm 9.8 \mathrm{a}(\mathrm{A})$ & $76.3 \pm 3.3 \mathrm{a}(\mathrm{A})$ & $61.1 \pm 1.7 \mathrm{~b}(\mathrm{~B})$ & $77.6 \mathrm{a} \pm 9.9 \mathrm{a}(\mathrm{A})$ & $69.5 \pm 0.5 \mathrm{ab}(\mathrm{A})$ & $68.5 \pm 2.3 \mathrm{~b}(\mathrm{~A})$ \\
\hline
\end{tabular}

Significant differences among $\mathrm{Hg}$ treatments are indicated by small different letter and among AM inoculation treatments with different capital letters (mean $\pm \mathrm{SD}, \mathrm{n}=3$; LSD's test, $\mathrm{p}<0.05$ )

seedlings was in the roots. There was no translocation of $\mathrm{Hg}$ to the aerial part (leaves) even though the $\mathrm{Hg}$ concentration in the growth media was higher. It indicates that E. cyclocarpum is not an $\mathrm{Hg}$ accumulator, but an $\mathrm{Hg}$ excluder. This result in line with some studies which have indicated that only a very small amount of $\mathrm{Hg}$ is translocated to plant shoot after root uptake and $\mathrm{Hg}$ in leaf mainly comes from the uptake of air Hg (Ericksen et al. 2004; Greger et al. 2005; Fay et al. 2007; Chen et al. 2009). Even though it was not an $\mathrm{Hg}$ accumulator, the potential of $E$. cyclocarpumas an $\mathrm{Hg}$ phytoremediation agent could be explored because the roots accumulated $\mathrm{Hg}$. Plants that accumulate $\mathrm{Hg}$ in the roots convert the pollutant into less available forms, thus they could be used to prevent Hg leaching and moving to other place.

In contrast, arbuscular mycorrhizal symbiosis tend to enhance nutrients ( $\mathrm{P}, \mathrm{Ca}$, and $\mathrm{Mg}$ ) uptake and translocation, especially in seedlings treated without $\mathrm{Hg}$ supply and $375 \mu \mathrm{M} \mathrm{Hg}$ supply (Table 2). Nevertheless the enhancement was not significant but as a single factor, $\mathrm{AM}$ inoculation enhanced $\mathrm{P}, \mathrm{Ca}$ and $\mathrm{Mg}$ uptake, significantly (Table 3). It is well documented that AM symbiosis can increase plant growth and nutrient uptake (Smith et al. 2008). However, AM symbiosis decreased nutrients (P and $\mathrm{Mg}$ ) translocation in seedlings treated with the highest Hg supply $(750 \mu \mathrm{M})$. We predict that disturbances of water fluxes altered $\mathrm{P}$ and $\mathrm{Mg}$ distribution due to high concentration $\mathrm{Hg}$ in growth substrate and also due to the existence of $\mathrm{P}$ and $\mathrm{Mg}$ competition between plant and AMF Gi. margarita in a limited space of pot experiment. Although a contribution of concentration effects after $\mathrm{Hg}$ supply cannot be ruled out, the increase of some nutrients could also be a strategy to avoid toxicity in plants (Moreno-Jiménez et al. 2007). In other case, the increase of nitrogen by nitrogen supply prevents oxidative stress in roots (Carrasco-Gil etal. 2012).

$\mathrm{Hg}$ can induce toxicity symptoms in plants such as inhibition of plant growth or disturbances on water and nutrient uptake (Patra at al. 2000). Mercury accumulated in plants evokes severe phytotoxicity and impairs numerous metabolic processes including nutrient uptake, water status, and photosynthesis (Chen et al. 2012). The inhibition of plant growth might be the first symptom of $\mathrm{Hg}$ stress (Cho et al. 2000). It was showed that $\mathrm{Hg}$ decreased significantly dry weight of 


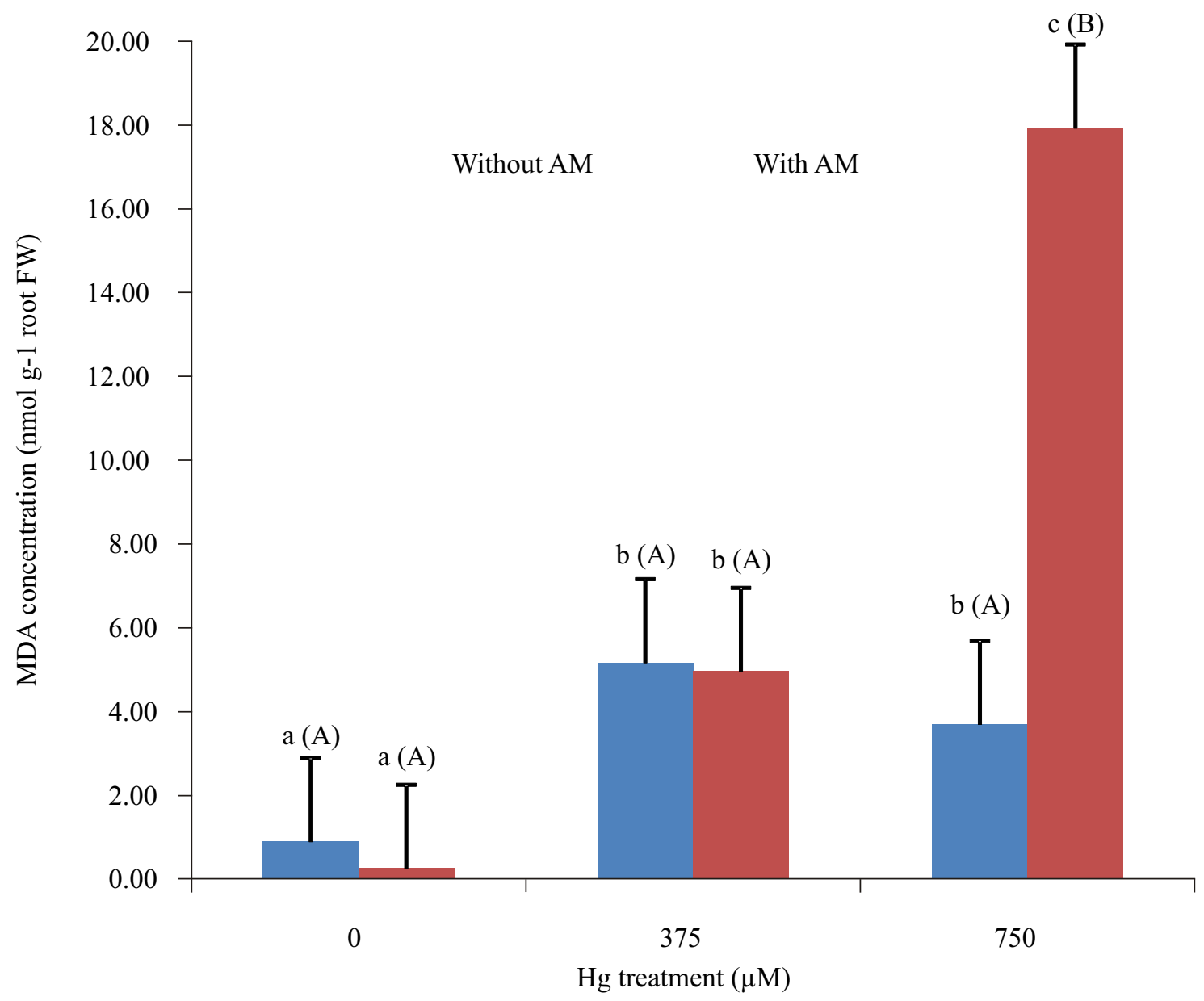

Fig 1 MDA concentration in roots of E. cyclocarpum seedlings with different $\mathrm{Hg}$ concentration (mean $\pm \mathrm{SD}, \mathrm{n}=3$ ). $\mathrm{Significant}$ differences among $\mathrm{Hg}$ treatments are indicated by small different letter and among AM inoculation treatments with different capital letters (LSD's test, $\mathrm{p}<0.05$ ).

Table 7 Tolerance index and AM colonization of E. cyclocarpum seedlings grown for $30 \mathrm{~d}$ in river sands with treatments of different $\mathrm{Hg}$ concentrations and $\mathrm{AM}$ inoculation

\begin{tabular}{ccccc}
\hline \multirow{2}{*}{$\mathrm{Hg}(\mu \mathrm{M})$} & \multicolumn{5}{c}{ AM inoculation } \\
\cline { 2 - 5 } & Without & With & Without & With \\
\hline & 100 & 100 & 0 & 65.9 \\
375 & 46.3 & 45.6 & 0 & 47.2 \\
750 & 54.2 & 66.9 & 0 & 40.8 \\
\hline
\end{tabular}

Remark: * The tolerance index was based on roots dry weight

roots, stems, and leaves of E. cyclocarpum seedlings during $30 \mathrm{~d}$ exposure to $\mathrm{Hg}$ supply (Table 4). The reduction of plant growth caused by $\mathrm{Hg}$ also been shown for Rumex induratus and Marrubium vulgare (Moreno-Jiménez et al. 2007). Generally, the formed mycorrhizal symbiosis significantly improved plant growth performance, such as plant height, stem diameter, shoot, root or total dry weight. In contrast, as a single factor of AM inoculation decreased dry weight of roots, stems and leaves significantly (Table 5), even though $\mathrm{AM}$ inoculation increased $\mathrm{P}, \mathrm{Ca}$, and $\mathrm{Mg}$ uptake (Table 3). We predicted that increase in $\mathrm{P}, \mathrm{Ca}$, and $\mathrm{Mg}$ uptake might be not followed by increase in other macro and micro nutrients. Therefore, increase in $\mathrm{P}, \mathrm{Ca}$ and $\mathrm{Mg}$ uptake was not followed by increase in plant dry weight. Additionally, growth depressions can be explained with respect to carbon $(\mathrm{C})$ demand and $\mathrm{P}$ supply by the AMF, where C drain to AMF was not 
imbalance to P supply from AMF (Grace et al. 2009). Kiers et al. (2011) stated that plants can detect, discriminate, and reward the best fungal symbionts with more carbohydrates and in turn, their fungal symbionts enforce cooperation by increasing nutrient transfer only to those roots providing more carbohydrates.

It has been addressed that $\mathrm{Hg}$ can disturbed water fluxes, therefore, it can alter nutrients distribution which depends on water movement within the xylem (Moreno-Jiménez et al. 2007). Considering now water content, in each organ of E. cyclocarpum seedlings did not suffer reduction in water content during $\mathrm{Hg}$ exposure. It indicated that water movement within the seedlings was not disturbed by $\mathrm{Hg}$ apply. Therefore, nutrients distribution ( $\mathrm{P}, \mathrm{Ca}$, and $\mathrm{Mg}$ ) in $E$. cyclocarpum seedlings were not inhibited, especially when the seedlings exposed to $\mathrm{Hg}$ up to $375 \mu \mathrm{M}$ concentration. This research only analyzed $\mathrm{P}, \mathrm{Ca}$, and $\mathrm{Mg}$ concentration, not other nutrients. Therefore, we cannot state if other nutrients translocation is affected. The role of AM inoculation to increase the water content of roots might be as an indirect strategy of seedlings to overcome $\mathrm{Hg}$-induced water stress when the roots contacted $\mathrm{Hg}$ directly. It has been known, extraradical hyphae of AMF can also increase water uptake in addition to nutrients uptake (Smith et al. 2008).

MDA is one of organic compounds has been used as a biomarker, which can be useful in the early diagnosis of metal toxicity (Prasad 2003). In our research, AM inoculation enhanced MDA concentration in roots, significantly, higher than non-mycorrhizal seedlings when exposed to the highest $\mathrm{Hg}(750 \mu \mathrm{M})$ treatment. It suggested some degree of oxidative stress, probably due to the high $\mathrm{Hg}$ concentration in the roots without any increase of the antioxidant (Moreno-Jiménez et al. 2007) in roots of mycorrhizal seedlings. In contrast, MDA concentration in roots of mycorrhizal seedlings was not different with roots of non-mycorrhizal seedlings when exposed to the lower $\mathrm{Hg}(375 \mu \mathrm{M})$ supply. Increases of MDA concentration by $\mathrm{Hg}$ exposure have been observed in some previous results research (Cho et al. 2000; Ortega-Villasante et al. 2005; Moreno-Jiménez et al. 2006; Esteban et al. 2008). However, it has not clear yet how its mechanism, especially in mycorrhizal plants when they were exposed to $\mathrm{Hg}$ and there is no information available, therefore further investigation is still needed. In other case, inoculation with AMF caused reduction in MDA content in comparison to salinized plants, indicating lower oxidative damage in the colonized plants (Latef et al. 2011). In our research, there was no effect of AM inoculation on MDA concentration in leaves but only $\mathrm{Hg}$ supply as a single factor resulted in the increased of MDA concentration in leaves, nevertheless, there was no $\mathrm{Hg}$ accumulation in leaves. It was probably due to indirect effect of $\mathrm{Hg}$ accumulation in roots. This presumption has to be proved in further study.

Roots of inoculated plants were colonized by AMF, while non-inoculated controls remained nonmycorrhizal (Table 7). However, the percentage of AM colonization was reduced in the presence of $\mathrm{Hg}$. This result indicated that the concentration of $\mathrm{Hg}$ supply in the substrate was harmful to AMF Gi. margarita. This finding is in line with Rabie (2005) who reported that sensitivity of AM symbionts to heavy metal polluted soil expressed as a reduction in root colonization. In contrast, addition of $\mathrm{Hg}$ in soil did not significantly influence maize root colonization rate (Yu et al. 2010). Another interesting result showed at Table 7, the presence of AMF could increase the metal tolerance index of E. cyclocarpum seedlings compared with nonmycorrhizal seedlings when they treated with $750 \mu \mathrm{M}$ Hg. This result emphasizes that AMF could be potentially effective in protecting seedlings exposed to high levels of $\mathrm{Hg}$ concentration. The AMF ability to alleviate heavy metals stress of plants grown in heavy metal polluted soil was previously proved by Rufyikiri et al. (2000); Hildebrandt et al. (2007). In contrast, tolerance index of mycorrhizal or non-mycorrhizal seedlings grown for $30 \mathrm{~d}$ in river sands treated with 375 $\mu \mathrm{M} \mathrm{Hg}$ was lower than seedlings treated with $750 \mu \mathrm{M}$ (Table 7). It might be related to $\mathrm{Hg}$ accumulation in roots treated with $375 \mu \mathrm{M} \mathrm{Hg}$ was higher than in roots treated with $750 \mu \mathrm{M} \mathrm{Hg}$ (Table 1) then resulted in the decreased of roots dry weight.

In conclusion, this study provides further evidence for the protective effects of AMF Gi. margarita on $E$. cyclocarpum against $\mathrm{Hg}$ contamination, i.e. non significant effect on $\mathrm{Hg}$ accumulation in roots, a tendency to increase nutrient uptake and translocation when seedlings treated with $\mathrm{Hg}$ supply up to $375 \mu \mathrm{M}$, the sharp decrease of dry biomass in seedlings, no different effect on water content in seedlings treated with $\mathrm{Hg}$ supply and no increase in MDA concentration in seedlings treated with $375 \mu \mathrm{M}$. It suggested that the role of symbiosis AMF Gi. margarita and E. cyclocarpum seedlings can tolerate up to $375 \mu \mathrm{M} \mathrm{Hg}$ supply. Even though, it is not yet clear if Gi. margarita could be applied for phytostabilization of $\mathrm{Hg}$ in contaminated sites. Considering the possible 
differences in AMF response to $\mathrm{Hg}$ in polluted soil from the field, more work needs to be done with AMF isolates that originate from $\mathrm{Hg}$-contaminated environments, to reveal the possible application of AMF in the management of $\mathrm{Hg}$ contaminated soils. Due to little information available on the potential role of AMF in plant accumulation of $\mathrm{Hg}$ and mechanisms involved, further studies are warranted.

\section{REFERENCES}

Brundrett M, Bougher N, Dell B, T Grove, Malajczuk N. 1996. Working with Mycorrhizas in Forestry and Agriculture. ACIAR Monograph $32.374+x$ p.

Carrasco-Gil S. Estebaranz-Yubero M, Medel-Cuestab D, Millán R, Hernández LE. 2012. Influence of nitrate fertilization on $\mathrm{Hg}$ uptake and oxidative stress parameters in alfalfa plants cultivated in a $\mathrm{Hg}$-polluted soil. Environmental and Experimental Botany 75:1624. doi:10.1016/j.envexpbot.2011.08.013.

Chen J, Yang ZM. 2012. Mercury toxicity, molecular response and tolerance in higher plants. BioMetals 25(5):847-857. doi:10.1007/s10534-012-9560-8.

Chen J, Shiyab S, Han FX, Monts DL, Waggoner CA, Yang $\mathrm{ZM}$, Su Y. 2009. Bioaccumulation and physiological effects of mercury in Pteris vittata and Nephrolepsis exaltata. Ecotoxocology 18(1):110-121. doi:10.1007/s1 0646-008-0264-3.

Cho UH, Park JO. 2000. Mercury-induced oxidative stress in tomato seedlings. Plant Sci. 156(1):1-9. doi:10.1016/ S0168-9452(00)00227-2

Ericksen JA, Gustin MS. 2004. Foliar exchange of mercury as a function of soil and air mercury concentrations. Sci Total Environ. 324(1-3):271-279. doi:10.1016/j.scitote nv.2003.10.034.

Esteban E, Moreno E, Peñalosa J, Cabrero JI, Millán R, Zornoza P. 2008. Short and long-term uptake of $\mathrm{Hg}$ in white lupin plants: Kinetics and stress indicators. Environmental and Experimental Botany 62(3):316322. doi:10.1016/j.envexpbot.2007.10.006.

Fay L, Gustin M. 2007. Assessing the influence of different atmospheric and soil mercury concentrations on foliar mercury concentrations in a controlled environment. Water Air Soil Poll. 181(1-4):373-384. doi:10.1007/s11 270-006-9308-6.

González-Chávez MC, Wright SF, Nichols KA. 2004. The role of glomalin, a protein produced by arbuscular mycorrhizal fungi, in sequestering potentially toxic elements. Enviro Poll. 130(3):317-323. doi:10.1016/j.e nvpol.2004.01.004

González-Guerrero M, Melville LH, Ferrol N, Lott JNA, Azcón-Aguilar C, Peterson RL. 2008. Ultrastructural localization of heavy metals in the extraradical mycelium and spores of the arbuscular mycorrhizal fungus Glomus intraradices. Can J Microbiol. 54(2):103-110. doi:10.1139/W07-119.

Grace EJ, Smith FA, Smith SE. 2009. Deciphering the
ArbuscularMycorrhizal Pathway of P Uptake in Nonresponsive Plant Species. In:Azcón-Aguilar C, Barea JM, Gianinazzi S, Gianinazzi-Pearson V. Editors. Mycorrhizas-Functional Processes and Ecological Impact. Springer-Verlag Berlin Heidelberg, pp: 89-106. doi:10.1007/978-3-540-87978-7.

Greger M, Wang Y, Neuschútz C. 2005. Absence of Hg transpiration by shoot after $\mathrm{Hg}$ uptake by roots of six terrestrial plant species. Environ Poll. 134(2):201-208. doi:10.1016/j.envpol.2004.08.007

Han FXX, Banin A, Su Y, Monts DL, Plodinec MJ, Kingery WL, Triplett GE. 2002. Industrial age anthropogenic inputs of heavy metals into the pedosphere. Naturwissenschaften 89(11):497-504. doi:10.1007/s00 114-002-0373-4.

Hildebrandt U, Regvar M, Bothe H. 2007. Arbuscular mycorrhiza and heavy metal tolerance. Phytochemistry 68(1):139-146. doi:10.1016/j.phytochem.2006.09.023.

Janoušková M, Pavlíková D, Vosátka M. 2006. Potential contribution of arbuscular mycorrhiza to cadmium immobilisation in soil. Chemosphere 65(11):19591965. doi:10.1016/j.chemosphere.2006.07.007.

Kiers ET, Duhamel M, Beesetty Y, Mensah JA, Franken O, Verbruggen E, Fellbaum CR,. Kowalchuk GA, Hart MM, Bago A, Palmer TM, West SA, Vandenkoornhuyse P, Jansa J, Bücking H. 2011. Reciprocal Rewards Stabilize Cooperation in the Mycorrhizal Symbiosis. Science 333(6044):880-882. www.sciencemag.org. doi:10.1126/science.1208473.

Latef AAHA, Chaoxing H. 2011. Effect of arbuscular mycorrhizal fungi on growth, mineral nutrition, antioxidant enzymes activity and fruit yield of tomato grown under salinity stress. Scientia Horticulturae 127(3):228-233. doi:10.1016/j.scienta.2010.09.020.

Marques APGC, Oliveira RS, Rangel AOSS, Castro PML. 2006. Zinc accumulation in Solanum nigrum is enhanced by different arbuscular mycorrhizal fungi. Chemosphere 65(7):1256-1263.

Moreno-Jiménez E, Gamarra R, Carpena-Ruiz RO, Millán $R$, Peñalosa JM, Esteban E. 2006. Mercury bioaccumulation and phytotoxicity in two wild plant species of Almaděn area. Chemosphere 63(11):19691973. doi:10.1016/j.chemosphere.2005.09.043.

Moreno-Jiménez E, Penalosa JM, Esteban E, Carpena RO. 2007. Mercury accumulation and resistance to mercury stress in Rume xinduratus and Marrubium vulgare grown on perlite. J. Plant Nutr. Soil Sci. 170(4): 485-494. doi:10.1002/jpln.200625238.

Ortega-Villasante C, Rellán-Alvarez R, Del Campo FF, Carpena Ruiz R O, Hernández LE. 2005. Cellular damage induced by cadmium and mercury in Medicago sativa. Journal of Experimental Botany 56(418):22392251. doi:10.1093/jxb/eri223

Patra M, Sharma A. 2000. Mercury toxicity in plants. Bot Rev. 66(3):379-422. doi:10.1007/BF02868923.

Prasad MNV. 2003. Biomarkers, in Prasad MNV, Hagemeyer J. Heavy Metal Stress in Plants. From Molecules to Ecosystem.2nd edition. Springer-Verlag, Berlin. pp. 445-448. 
Rabie GH. 2005. Contribution of arbuscularmycorrhizal fungus to red kidney and wheat plants tolerance grown in heavy metal-polluted soil. Afr J Biotechnol. 4(4):332-345

Rodríguez L, Rincón J, Asencio I, Rodríguez-Castellanos L, 2007. Capability of selected crop plants for shoot mercury accumulation from polluted soils: Phytoremediation perspectives. International Journal of Phytoremediation 9(1):1-13. doi:10.1080/15226510 601139359.

Rufyikiri G, Declerck, S, Dufey JE, Delvaux B. 2000. Arbuscular mycorrhizal fungi might alleviate aluminium toxicity in banana plants. New Phytol. 148(2):343-352. doi:10.1046/j.1469-8137.2000.00761.x.

Sierra MJ, Millán R, Esteban E, Cardona AI, Schmid T. 2008. Evaluation of mercury uptake and distribution in Vicia sativa L. applying two different study scales: Greenhouse conditions and lysimeter experiments. Journal of Geochemical Exploration 96(2-3):203-209. doi:10.1016/j.gexplo.2007.04.013.

Smith SE, Read DJ. 2008. Mycorrhial Symbiosis. Third Edition. Great Britain: Academic Press.

[US-EPA] US-Environmental Protection Agency. 2009. Potential Export of Mercury Compounds from the
United States for Conversion to Elemental Mercury. Report to Congress. Washington, DC: Office of Pollution Prevention and Toxic Substances.

Wang Y, Greger M. 2004. Plant and environment interactions: Clonal differences in mercury tolerance, accumulation, and distribution in willow. J Environ Qual.33(5):779-1785. doi:10.2134/jeq2004.1779.

World Agroforestry Centre. 2013. A tree species reference and selection guide. AgroForestryTree Database. PROSEA. http://www.worldagroforestrycentre.org/sea/ products/afdbases/af/asp/SpeciesInfo.asp?SpID=734 [cited December 6, 2013].

Yu Y, Zhang S, Huang H. 2010. Behavior of mercury in a soil-plant system as affected by inoculation with the arbuscular mycorrhizal fungus Glomus mosseae. Mycorrhiza 20(6):407-414. doi:10.1007/s00572-0090296-4.

Zornoza P, Millan R, Sierra MJ, Seco A, Esteban E. 2010. Efficiency of white lupin in the removal of mercury from contaminated soils: Soil and hydroponic experiments. J Environ Sci. 22(3):421-427. doi:10.1016 /S1001-0742(09)60124-8. 